$\mathrm{DE}$

M E D I C I N A

T R O P I C A L

$\mathrm{DE}$

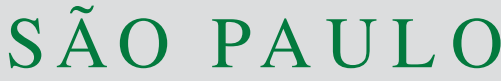

JOURNAL OF THE SÃO PAULO INSTITUTE OF TROPICAL MEDICINE

1 Universidade Federal Fluminense, Faculdade de Veterinária, Programa de Pós-Graduação em Medicina Veterinária (Clínica e Reprodução Animal), Niterói, Rio de Janeiro, Brazi

2Universidade Federal Fluminense, Faculdade de Veterinária, Departamento de Patologia e Clínica Veterinária, Niterói, Rio de Janeiro, Brazil

${ }^{3}$ Fundação Oswaldo Cruz (FIOCRUZ), Laboratório de Hantaviroses e Rickettsioses, Rio de Janeiro,

Rio de Janeiro, Brazil

${ }^{4}$ Fundação Oswaldo Cruz Mato Grosso do Sul (FIOCRUZ MS), Campo Grande, Mato Grosso do Sul, Brazil

Correspondence to: Beatriz Teixeira Gomes da Silva

Universidade Federal Fluminense, Faculdade de Veterinária, Programa de Pós-Graduação em Medicina Veterinária (Clínica e Reprodução Animal), Rua Vital Brasil Filho, 64, CEP 24230-340, Niterói, RJ, Brazil

E-mail: beatriztgs@ @otmail.com

Received: 30 November 2017

Accepted: 20 December 2017

\section{Presence of Bartonella spp. in domestic cats from a state park in Rio de Janeiro, Brazil}

Niterói, November 30, 2017

Bacteria of genus Bartonella are worldwide distributed and responsible for several diseases in human and animal hosts ${ }^{1}$. They are facultative intracellular microorganisms and remain for long periods in bloodstream, allowing continuous transmission by arthropods during blood-feeding ${ }^{2}$. Cat-scratch disease is caused by Bartonella henselae. Cats are considered the main reservoir of this bacterium, which is usually transmitted to cats by arthropods, such as Ctenocephalides felis flea $^{3}$.

The pathogen is well adapted to its reservoir, and feline hosts are often asymptomatic ${ }^{2,4}$. However, cats can develop febrile illness and endocarditis ${ }^{5}$.

Transmission of $B$. henselae between cats occurs through contamination of skin wounds with flea feces ${ }^{3}$, and cats transmit the organism to humans via scratching, biting or saliva ${ }^{6}$. In immunocompetent humans $B$. henselae infection is usually selflimited, characterized by regional lymphadenopathy with or without other clinical abnormalities, such as fever or fatigue. Occasionally, long-term intraerythrocytic bacteremia can be observed, as well as infection by other species of the genus, including Bartonella clarridgeiae and Bartonella quintana ${ }^{2}$.

We now aimed to demonstrate the presence of Bartonella sp. in domestic cats inhabiting the Serra da Tiririca State Park (PESET), a preserved area located within the municipalities of Niterói and Maricá, State of Rio de Janeiro, Brazil, which is part of the Atlantic rainforest biome; harboring a large diversity of endemic fauna and flora constituting an important ecotourism area for human visitors. Unfortunately, the park has been damaged due to inadequate housing construction, increase in human and animal populations living improperly inside or on the edge of the park acts of vandalism, fire, hunting and inadequate garbage disposal ${ }^{7}$.

This study was approved by the Ethics Commission on Animal Use (CEUA) from Universidade Federal Fluminense (process $N^{\circ}$ 677). We collected blood samples from 89 domestic cats living in households and free-roaming cats at PESET. DNA extraction from blood samples was performed with the Illustra ${ }^{\mathrm{TM}}$ blood genomic Prep Mini Spin Kit (GE Healthcare). Samples were processed by conventional polymerase chain reaction (PCR) targeting a fragment of the citrate synthase gene of Bartonella spp. with the primers BhCS781p (GGGGACCAGCTCATGGTGG) and BhCS1137n (AATGCAAAAAGAACAGTAA ACA) ${ }^{8}$. Positive results were obtained in $24.72 \%$ (22/89) of the PCR assays. In Brazil, the prevalence of Bartonella among cats has been found to range from $1.6 \%-97 \%{ }^{9-12}$, however, only in the present study the occurrence of this bacterium was demonstrated in one preservation and ecotourism area.

We found this case to be noteworthy because we observed a high frequency of Bartonella-infected cats in the study area. We emphasize the possibility that cats living illegally in PESET are an important source of infection both for other cats and for humans, since the park has a visitor area where humans can interact with these cats. Immunosuppressed people should avoid contact with any unknown cat since they can acquire bartonellosis and the pathologic response varies according to the host immune status. Further studies are needed, including sequencing of 
positive samples, in order to identify the species involved in study area.

\section{Beatriz Teixeira Gomes da Silva Aline Moreira de Souza ${ }^{2}$ Sabrina Destri Emmerick Campos ${ }^{1}$ Elba Regina Sampaio de Lemos Alexsandra Rodrigues de Mendonça Favacho ${ }^{4}$ Nádia Regina Pereira Almosny ${ }^{2}$}

\section{REFERENCES}

1. Hegarty BC, Bradley JM, Lappin MR, Balakrishnan N. Mascarelli PE, Breitschwerdt EB. Analysis of seroreactivity against cell culture-derived Bartonella spp. antigens in dogs. J Vet Intern Med. 2014;28:38-41.

2. Harms A, Dehio C. Intruders below the radar: molecular pathogenesis of Bartonella spp. Clin Microbiol Rev. 2012;25:42-78

3. Foil L, Andress E, Freeland RL, Roy AF, Rutledge R, Triche PC, et al. Experimental infection of domestic cats with Bartonella henselae by inoculation of Ctenocephalides fells (Siphonaptera: Pulicidae) feces. J Med Entomol. 1998;35:625-8.

4. Stützer B, Hartmann K. Chronic Bartonellosis in cats: what are the potential implications? J Feline Med Surg. 2012;14:612-21.

5. Guptill L. Bartonella infections in cats: what is the significance? In Pract. 2012;34:434-45.
6. Tsai YL, Lin CC, Chomel BB, Chuang ST, Tsai KH, Wu WJ, et al. Bartonella infection in shelter cats and dogs and their ectoparasites. VectorBorne Zoonotic Dis. 2011;11:1023-30.

7. Rio de Janeiro. Instituto Estadual do Ambiente. Resumo executivo: plano de manejo: Parque Estadual da Serra da Tiririca - PESET. Rio de Janeiro: INEA; 2012.

8. Norman AF, Regnery R, Jameson P, Greene C, Krause DC. Differentiation of Bartonella-like isolates at the species level by PCR-restriction fragment length polymorphism in the citrate synthase gene. J Clin Microbiol. 1995;33:1797-803.

9. Staggemeier R, Venker CA, Klein DH, Petry M, Spilki FR, Cantarelli VV. Prevalence of Bartonella henselae and Bartonella clarridgeiae in cats in the south of Brazil: a molecular study. Mem Inst Oswaldo Cruz. 2010;105:873-78.

10. Souza AM, Almeida DN, Gutierres A, Gomes R, Favacho AR, Moreira NS, et al. Bartonelose: análise molecular e sorológica em gatos do Rio de Janeiro - Brasil. Rev Bras Cienc Vet. 2010;17:7-11.

11. Braga MD, Diniz PP, André MR, Bortoli CP, Machado RZ. Molecular characterisation of Bartonella species in cats from São Luís, state of Maranhão, north-eastern Brazil. Mem Inst Oswaldo Cruz. 2012;107:772-7.

12. Braga IA, Dias IS, Chitarra CS, Amude AM, Aguiar DM. Molecular detection of Bartonella clarridgeiae in domestic cats from Midwest Brazil. Braz J Infect Dis. 2015;19:451-2. 